\title{
A new mtDNA COI gene lineage closely related to Anopheles janconnae of the Albitarsis complex in the Caribbean region of Colombia
}

\author{
Lina A Gutiérrez¹/+, Lina M Orrego', Giovan F Gómez', Andrés López², \\ Shirley Luckhart ${ }^{3}$, Jan E Conn ${ }^{4,5}$, Margarita M Correa ${ }^{1}$ \\ ${ }^{1}$ Grupo de Microbiología Molecular, Escuela de Microbiología, Universidad de Antioquia, Calle 67 53-108, 5-430, Medellín, Colombia \\ ${ }^{2}$ Grupo de Investigación en Sistemática Molecular, Universidad Nacional de Colombia sede Medellín, Medellín, Colombia \\ ${ }^{3}$ Department of Medical Microbiology and Immunology, University of California, Davis, CA, USA \\ ${ }^{4}$ Griffin Laboratory, Wadsworth Center, New York State Department of Health, NY, USA \\ ${ }^{5}$ Department of Biomedical Sciences, School of Public Health, State University of New York, Albany, NY, USA
}

\begin{abstract}
An understanding of the taxonomic status and vector distribution of anophelines is crucial in controlling malaria. Previous phylogenetic analyses have supported the description of six species of the Neotropical malaria vector Anopheles (Nyssorhynchus) albitarsis s.l. (Diptera: Culicidae): An. albitarsis, Anopheles deaneorum, Anopheles marajoara, Anopheles oryzalimnetes, Anopheles janconnae and An. albitarsis $F$. To evaluate the taxonomic status of An. albitarsis s.l. mosquitoes collected in various localities in the Colombian Caribbean region, specimens were analyzed using the complete mitochondrial DNA cytochrome oxidase I(COI) gene, the ribosomal DNA (rDNA) internal transcribed spacer 2 (ITS2) region and partial nuclear DNA white gene sequences. Phylogenetic analyses of the COI gene sequences detected a new lineage closely related to An. janconnae in the Caribbean region of Colombia and determined its position relative to the other members of the complex. However, the ITS2 and white gene sequences lacked sufficient resolution to support a new lineage closely related to An. janconnae or the An. janconnae clade. The possible involvement of this new lineage in malaria transmission in Colombia remains unknown, but its phylogenetic closeness to An. janconnae, which has been implicated in local malaria transmission in Brazil, is intriguing.
\end{abstract}

Key words: Colombia - Albitarsis complex - Anopheles janconnae - malaria - COI - white gene - ITS2

By 2006 , an estimated $9.4 \%$ of the total Colombian population was living in moderate or high-risk areas for malaria transmission; the Annual Parasite Index, the number of confirmed malaria cases per 1,000 inhabitants, was an average of 26.2 (PAHO 2007). In 2007, the National Health Institute (INS) of Colombia reported 110,480 cases of malaria caused by Plasmodium vivax Grassi \& Felleti and Plasmodium falciparum Welch (Coccidia: Plasmodiidae).

Because many important malaria vectors are in cryptic species complexes, it is essential to precisely identify species and to clarify their phylogenetic status to better understand patterns of malaria transmission. Several studies have defined the taxonomic status and phylogenetic relationships among members of the Albitarsis complex using nuclear and mitochondrial markers (Lehr et al. 2005, Merritt et al. 2005, Wilkerson et al. 2005, Brochero et al. 2007, Li \& Wilkerson 2007) and researchers have shown that the Albitarsis complex consists of at least six species, including Anopheles albitarsis Lynch-Arribálzaga, Anopheles deaneorum Rosa-Freitas, 1989, Anopheles marajoara Galvão \& Damasceno, An. albitarsis B (Wilk-

Financial support: CODI, Universidad de Antioquia, (8700-039 to MMC), NIH (R03AI076710 to MMC and 2R01AI054139 to JEC), COLCIENCIAS (to LAG for doctoral training)

+ Corresponding author: liangutibui@gmail.com

Received 12 June 2010

Accepted 5 November 2010 erson et al. 1995a, b, 2005), An. albitarsis E (Lehr et al. 2005) and An. albitarsis F (Brochero et al. 2007). Recently, Motoki et al. (2009) presented morphological descriptions of adult males and females, fourth-instar larvae and pupae of An. albitarsis, An. marajoara, An. deaneorum and An. albitarsis $\mathrm{B}$ and adult males and females of An. albitarsis $\mathrm{E}$. These authors also validated and named species $\mathrm{B}$ and $\mathrm{E}$ as Anopheles oryzalimnetes Wilkerson \& Motoki and Anopheles janconnae Wilkerson \& Sallum, respectively. However, species $\mathrm{F}$ has yet to be formally described. Furthermore, a new study has determined that An. deaneorum is a complex (Bourke et al. 2010) and thus the number of species in the Albitarsis complex is no doubt more than six.

Species of the Albitarsis complex have been reported in several South American countries (Lehr et al. 2005, Li \& Wilkerson 2005, Brelsfoard et al. 2006, Brochero et al. 2007, Motoki et al. 2009). Some of these species seem to be allopatric. However, sympatric distributions have been recorded for An. marajoara and An. deaneorum, An. oryzalimnetes (as An. albitarsis $\mathrm{B}$ ) and An. albitarsis, in Brazil (Wilkerson et al. 1995a, b, Lehr et al. 2005) as well as An. albitarsis $\mathrm{F}$ and An. marajoara in Colombia (Brochero et al. 2007). Based primarily on morphological identification, An. marajoara has been recorded in 25 of the 32 Colombian departments (González \& Carrejo 2007) and in a study in Villavicencio, eastern Colombia, An. marajoara was highly abundant and widely distributed in urban areas, suggesting its efficient adaptation to human environments (Brochero et al. 2005). An. albitarsis $\mathrm{F}$ is suspected as a malaria vector in the Department of Vichada, eastern Colombia (Brochero et al. 2007). 
Among members of the Albitarsis complex, $A n$. marajoara (Rubio-Palis \& Zimmerman 1997, Conn et al. 2002) and An. janconnae (as An. albitarsis E) (Póvoa et al. 2006) have been incriminated as malaria vectors, $A n$. deaneorum is suspected as a vector (Klein et al. 1991a, b) and An. albitarsis, An. oryzalimnetes and An. albitarsis $\mathrm{F}$ do not have a defined role in transmission. In Colombia, a recent study on the natural Plasmodium infectivity of Anopheles species from the Caribbean and Pacific regions reported the presence of An. albitarsis s.l. in three of the seven localities investigated: Santa Rosa de Lima (SRL), Moñitos (MON) and Tumaco (Gutiérrez et al. 2008). However, all of the specimens analyzed were uninfected, probably due to the small sample size. To further define the distributions of species of the Albitarsis complex in Colombia, we used three molecular markers, including the complete mitochondrial cytochrome oxidase I (COI) gene sequence, the internal transcribed spacer 2 (ITS2) region of the ribosomal DNA (rDNA) sequence and a sequence fragment of the single copy nuclear white gene, to identify the species of the Albitarsis complex in several localities in the Colombian Caribbean region. Phylogenetic analyses based on the COI sequences identified the specimens as a new lineage closely related to An. janconnae.

\section{MATERIALS AND METHODS}

Mosquito collection - Adult mosquitoes were wildcaught. Collection data and species identification for the mosquitoes from SRL and MON have previously been published in Gutiérrez et al. (2008). An. albitarsis s.l. specimens previously collected in Puerto Libertador (PLT), Córdoba Department (Gutiérrez et al. 2009), were also included in this study. Species-specific ITS2 regions were amplified from mosquitoes morphologically identified as An. albitarsis s.l. following the scheme proposed by Li and Wilkerson (2005) (Table I). The collection locations of the putative and described species of the Albitarsis complex, which are based on the COI and ITS2 sequences available in GenBank and those tested in this study, were depicted using DIVA-GIS software version 5.2.0.2 (Fig. 1) (Hijmans et al. 2001).
DNA extraction, polymerase chain reaction (PCR) amplification and sequencing - Total DNA was extracted from individual abdomens of An. albitarsis s.l. mosquitoes using a salt precipitation protocol (Birungi \& Munstermann 2002) or DNeasy ${ }^{\circledR}$ Blood \& Tissue Kit (QIAGEN, Duesseldorf, Germany). Three molecular markers were amplified, sequenced and

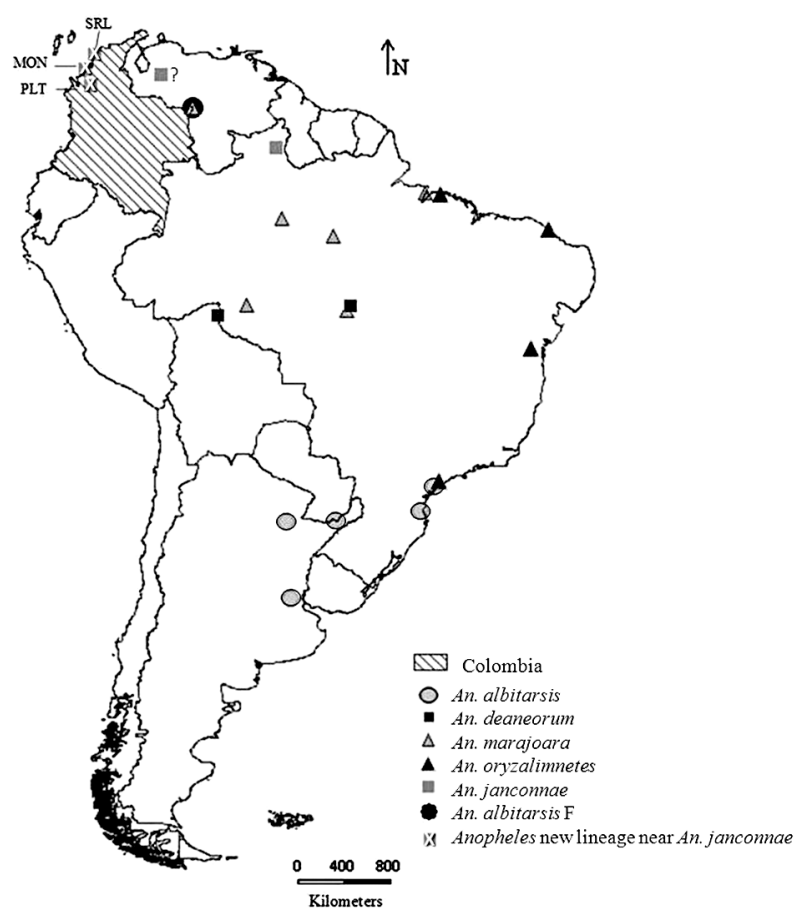

Fig. 1: location of putative and described species of the Albitarsis complex based on cytochrome oxidase I (COI) and internal transcribed spacer 2 sequences available in GenBank and obtained in this study. Based on the COI gene phylogenetic analyses the three populations from the Caribbean region of Colombia are in the same clade as the sample of Anopheles albitarsis E from Venezuela and closely related to Anopheles janconnae from the type locality in Northern Brazil. MON: Moñitos; PLT: Puerto Libertador; SRL: Santa Rosa de Lima.

TABLE I

Collection and molecular data for Anopheles albitarsis s.1.

\begin{tabular}{|c|c|c|c|c|c|c|c|}
\hline Department & Locality & $\begin{array}{c}\text { Mosquitoes } \\
\text { collected } \\
\text { (n) }\end{array}$ & $\mathrm{PCR} \mathrm{ITS}^{a}{ }^{a}$ & $\mathrm{COI}^{b}$ & ITS $2^{b}$ & white gene ${ }^{b}$ & Coordinates \\
\hline Bolívar & SRL & 73 & 73 & 6 & 5 & 1 & $10^{\circ} 26^{\prime} \mathrm{N} 75^{\circ} 21^{\prime} \mathrm{W}$ \\
\hline \multirow[t]{2}{*}{ Córdoba } & MON & 2 & 2 & 1 & 2 & $*$ & $9^{\circ} 15^{\prime} \mathrm{N} 76^{\circ} 06^{\prime} \mathrm{W}$ \\
\hline & PLT & 10 & 10 & 7 & 5 & 1 & $7^{\circ} 54^{\prime} \mathrm{N} 75^{\circ} 40^{\prime} \mathrm{W}$ \\
\hline
\end{tabular}

$a$ : number of specimens identified using the internal transcribed spacer 2 (ITS2) polymerase chain reaction (PCR) strategy in $\mathrm{Li}$ and Wilkerson (2005); $b$ : number of specimens from each locality with DNA sequences for the respective marker; COI: cytochrome oxidase I gene; MON: Moñitos; PLT: Puerto Libertador; SRL: Santa Rosa de Lima. Asterisk means that the white gene PCR amplification failed for specimens from MON. 
analyzed: (i) the ITS2 of the rDNA using primers and PCR conditions previously described (Li \& Wilkerson et al. 2005, Zapata et al. 2007), (ii) the complete COI gene amplified using two sets of conserved primer pairs described in Lunt et al. (1996) and (iii) the partial sequence of the single copy nuclear white gene amplified using the PCR conditions recommended by Mirabello and Conn (2008). The COI and white gene PCR reactions were performed using PuReTaq ${ }^{\mathrm{TM}}$ Ready-To-Go ${ }^{\mathrm{TM}}$ PCR beads (GE Healthcare, UK) containing $0.4 \mu \mathrm{M}$ of each primer in $25-\mu \mathrm{L}$ volumes. The ITS2 PCR reactions were performed using BIOTAQ $^{\mathrm{TM}}$ DNA Polymerase (Bioline, London, UK). The PCR products were purified using CentriSpin 40 columns (Princeton Separations, Adelphia, NJ) or the Wizard SV Gel and PCR Clean-Up System (Promega, Madison, WI). Fragments were sequenced in both directions at the Applied Genomic Technologies Core facility of the Wadsworth Center, New York State Department of Health, Albany, NY. The nucleotide sequences were compiled and edited using Sequencher 3.0 (Gene Codes Corporation, Ann Arbor, MI).
Multiple sequence alignment - Using CLUSTALX 1.83 (Thompson et al. 1997), 12 ITS2 and two white gene sequences from the An. albitarsis s.l. specimens obtained in this study (Table I) were aligned with the available ITS2 and white gene sequences from GenBank (Table II), which correspond to An. marajoara, An. albitarsis, An. deaneorum, An. oryzalimnetes and An. albitarsis $\mathrm{F}$ (Thompson et al. 1997). All the positions that contained alignment gaps and missing data were eliminated for pairwise sequence comparisons (pairwise deletion option). Neighbour-joining (NJ) analyses were conducted in MEGA4 (Tamura et al. 2007). Additionally, the COI DNA sequences from 14 specimens, representing the three collection sites (Table I) were aligned with DNA sequences available in GenBank for An. albitarsis, An. marajoara, An. oryzalimnetes, An. deaneorum and An. janconnae (Table II). In most of the phylogenetic analyses conducted in this study, Anopheles darlingi Root and Anopheles braziliensis Chagas were included as the outgroup. The COI, ITS2 and white gene sequences from the present study are deposited in GenBank under the following accessions: ITS2, GQ153583-GQ153594, white gene, GQ153595-GQ153596 and COI, GQ153597-GQ153610.

TABLE II

Sequences for Anopheles albitarsis s.1. from GenBank used in the alignments

\begin{tabular}{|c|c|c|c|}
\hline Species & ITS2 & white gene & $\mathrm{COI}$ \\
\hline An. albitarsis & $\begin{array}{c}\text { DQ077807, } \\
\text { AY828334-AY828336 } \\
\text { AY828320-AY828323 } \\
\text { AF462385-AF462387, } \\
\text { U92332 }\end{array}$ & AF318198, AY956300, AY956299 & DQ076204-DQ076209 \\
\hline Anopheles oryzalimnetes & $\begin{array}{c}\text { AY828324-AY828327, } \\
\text { AY828337, AY828338 } \\
\text { U92333 }\end{array}$ & AY956297, AY956298 & DQ076210-DQ076215 \\
\hline Anopheles janconnae & $*$ & $*$ & DQ076231-DQ076234 \\
\hline An. albitarsis $\mathrm{F}$ & DQ228315 & DQ228314 & $*$ \\
\hline Anopheles deaneorum & $\begin{array}{c}\text { AF461751, AF461752, } \\
\text { AY828330-AY828333, } \\
\text { AY828341-AY828343, } \\
\text { U92335 }\end{array}$ & AY956301- AY956302 & DQ076226-DQ076230 \\
\hline Anopheles marajoara & $\begin{array}{c}\text { DQ364141, AY028127, } \\
\text { DQ077808, } \\
\text { DQ848153, AY828328, } \\
\text { AY828329, } \\
\text { AY828339-AY828341, } \\
\text { AY828344-AY828354, } \\
\text { U92334 }\end{array}$ & $\begin{array}{c}\text { DQ906919, DQ906920, } \\
\text { DQ848154, AY956295, } \\
\text { AY956296 }\end{array}$ & DQ076216-DQ076221 \\
\hline Anopheles darlingi & AF462389 & GQ285644 & DQ076235, DQ076236 \\
\hline Anopheles braziliensis & AF461753 & $*$ & DQ076237, DQ076238 \\
\hline Anopheles albimanus & $*$ & L76302 & $*$ \\
\hline
\end{tabular}

Anopheles darlingi, Anopheles braziliensis and Anopheles albimanus are outgroup. COI: cytochrome oxidase I gene; ITS2: internal transcribed spacer 2. Asterisks mean no data available in GenBank at time analyses were conducted. 
Phylogenetic analyses based on the complete mitochondrial DNA (mtDNA) COI gene - Both maximum parsimony (MP) and maximum likelihood (ML) analyses were implemented in PAUP version 4.0b10 (Swofford 2000). For the MP analysis, optimal trees were generated using the heuristic search option with the tree bisectionreconnection (TBR) branch-swapping algorithm. Multiple trees were saved for each run. Bootstrap support values were generated from 1,000 pseudoreplicates. For the ML analysis, an appropriate model of nucleotide substitutions was determined using the program Modeltest 3.8 (Posada 2006); we chose to use the Akaike information criterion (AIC). Bootstrap support values with the heuristic search option and the TBR algorithm chosen for branch-swapping were generated from 662 pseudoreplicates. Bayesian analysis was performed using Mr Bayes version 3.1.2 (Ronquist \& Huelsenbeck 2003). Bayesian inference was conducted using the program default values for the prior probabilities, performing two runs with four independents chains. The Markov chain Monte Carlo algorithm was allowed to run 10,000,000 generations and to sample every 100 generations after a burn-in of $2,500,000$ generations (25,000 trees). Convergence was assessed based on results from three different parameters (i) the decrease in the average standard deviations of split frequencies ranging from 1-0, (ii) the estimated parameters using the sump command and (iii) the plot of generation vs. the log probability of observing the data.

\section{RESULTS}

ITS2 and white gene analyses - The ITS2-PCR analyses showed that the An. albitarsis s.l. mosquitoes collected from the Caribbean region corresponded to the molecular pattern reported for An. marajoara (Fig. 2). However, it is important to note that the ITS2-PCR analyses (Li \& Wilkerson 2005) only identify the species An. marajoara, An. deaneorum, An. albitarsis and An. oryzalimnetes and subsequent analysis added species $\mathrm{F}$ to the previous scheme (Brochero et al. 2007). Therefore, further analyses using additional markers were performed to determine the identity of the An. albitarsis s.l. specimens from the three Colombian localities.

The ITS2 sequences obtained from specimens collected in SRL, MON and PLT showed $100 \%$ identity among them and white gene sequences from SRL and PLT were also identical. A BLASTN search (GenBank) based on ITS2 and white gene sequences of samples from the Caribbean region detected $99 \%$ identity with an ITS2 sequence, which corresponds to An. marajoara from Chocó, Colombia (accession AY028127) and shares a 98\% identity with a white gene sequence reported as An. marajoara from Puerto Carreño, Colombia (accession DQ906920). In this study, NJ analyses based on ITS2 sequences basically clustered all sequences into two groups. One group included all the species of the Albitarsis complex and the other group included sequences from both An. darlingi and An. braziliensis. The NJ tree based on white gene sequences showed individual clustering for An. albitarsis, An. deaneorum and An. albitarsis $\mathrm{F}$ as well as one sequence of $A n$. oryzalimnetes clustered with An. albitarsis. Samples from this study, collected in the Caribbean region, clustered with sequences of An. marajoara (Supplementary data).
$\mathrm{COI}$ gene analyses - COI sequences from An. albitarsis s.l. collected in the Caribbean localities produced an alignment without indels, with 31 variable and four parsimony informative sites, all at the third nucleotide position. Alignment of all the COI sequences from the Albitarsis complex specimens from this work and GenBank detected 209 (14.2\%) variable and 155 (10.5\%) parsimony informative sites distributed at the first and third nucleotide positions in the alignment. The strict consensus of the 14 most parsimonious trees was estimated (Supplementary data). A ML tree (Supplementary data). was estimated considering the best-fit DNA substitution model selected using the AIC criterion (general time reversible model: GTR $+\mathrm{I}+\mathrm{G}$ ) for 1,470 sites of the COI dataset (Tavaré 1986), with invariable sites $(I=0.7261)$ and a gamma distribution shape parameter $(G=1.1297)$. The Bayesian analysis was visualized using the majority rule consensus tree employing the GTR $+\mathrm{I}+\mathrm{G}$ model and six categories of rates (Fig. 3). Results for the ML (662 replicates), MP (1,000 replicates) and Bayesian inference trees based on COI sequence analyses, including An. darlingi and An. braziliensis as outgroups, illustrated a similar topological conformation. Three sequences of An. janconnae from the type locality of Roraima (RR), Brazil, consistently grouped together with high bootstrap support ( 96 for each of MP and ML, 1.00 for Bayesian inference), whereas the specimens from the Colombian Caribbean localities consistently grouped with one sequence of purported An. janconnae from Portuguesa, Venezuela (Fig. 1). In summary, monophyly of the $A n$. albitarsis, An. oryzalimnetes and An. deaneorum clades was observed under MP, ML and Bayesian analyses. $A n$. marajoara was consistently more closely related to $A n$. deaneorum and An. oryzalimnetes to An. albitarsis. An. janconnae (as An. albitarsis E) (Fig. 3 and Supplementary data) is polyphyletic. The mean genetic distance (GTR and Kimura 2-parameter models) computed using pairwise comparisons was 0.028 (range 0.024-0.031) for the different specimens of An.janconnae from Venezuela and Brazil and were comparable with specimens from the Caribbean region of Colombia.

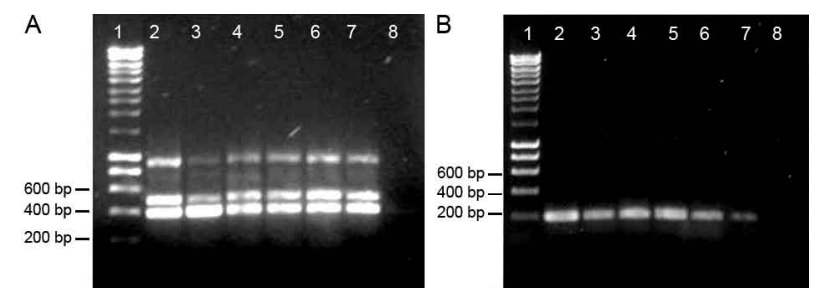

Fig. 2: polymerase chain reaction (PCR) products from internal transcribed spacer 2 (ITS2) analyses. A: PCR amplification using specific ITS2 primers albCD, ITS2F and ITS2R, observed patterns are diagnostic for Anopheles marajoara and Anopheles deaneorum; B: PCR amplification using specific ITS2 primers albC, ITS2F and ITS2R, observed patterns are diagnostic for $A n$. marajoara ( 194 bp); Lane 1: DNA ladder; 2-7: amplicons corresponding to Anopheles albitarsis s.l. specimens from Santa Rosa de Lima (SRL); 2: SRL55; 3: SRL56; 4: SRL57; 5: SRL58; 6: SRL59; 7 : SRL60; 8: PCR negative control. 


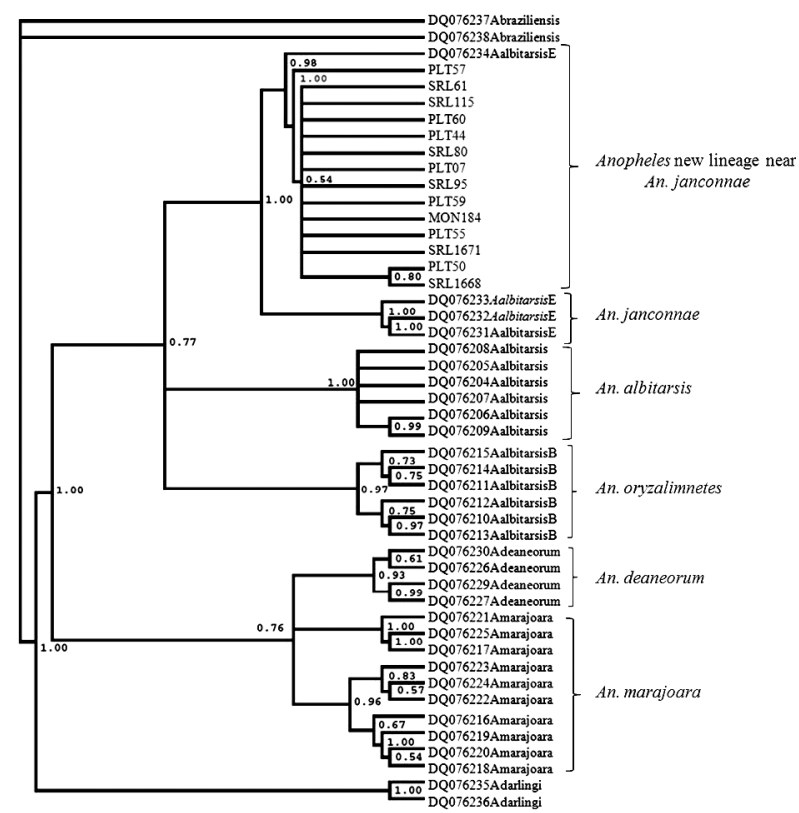

Fig. 3: Bayesian topology of the cytochrome oxidase I sequences. Numbers above branches indicate posterior probabilities. DQ076234: Anopheles albitarsis E (?) specimen from Portuguesa, Venezuela; DQ076231-DQ076233: An. albitarsis E (Anopheles janconnae) from the type locality in Roraima, Brazil. Outgroup comprises Anopheles darlingi and Anopheles braziliensis.

\section{DISCUSSION}

In this study, after applying the scheme to identify specimens of the Albitarsis complex from Caribbean localities to species based on ITS2-PCR (Li \& Wilkerson 2005), it was not possible to determine whether they were An. marajoara, An. janconnae or a new lineage closely related to An. janconnae. However, phylogenetic analyses of mitochondrial COI gene sequences of $\mathrm{An}$. albitarsis s.l. specimens from the Caribbean localities in Colombia (Fig. 3 and Supplementary data) strongly supported monophyly with specimens previously identified as An. albitarsis E from Venezuela (Lehr et al. 2005), but not with An. janconnae from the type locality in RR.

The DNA sequences from ribosomal and nuclear genes placed sequences of a new lineage closely related to An. janconnae and An. janconnae in close relationship to An. marajoara. Results of the NJ analyses of the ITS2 is unresolved with most sequences clustered as a polytomy and the white gene topology showed the new lineage closely related to An. janconnae within a strongly supported clade ( $99 \%$ bootstrap support) formed by An. marajoara. The NJ analyses showed that genetic differentiation for species of the Albitarsis complex based on the ITS2 and white gene sequences lacked sufficient resolution to support a new lineage closely related to An. janconnae or the An. janconnae clade, probably due to the following: (i) homoplasy, (ii) lineage divergence within the Albitarsis complex is still undetectable using these molecular markers, in particular among An. marajoara, the new lineage closely related to An. janconnae and An. janconnae and/or (iii) the possibility that the mtDNA lineages are the result of allopatric fragmentation rather than speciation. This result suggests that the ITS2 and single copy nuclear white gene markers have limitations in discriminating between the incipient or recently separated species/lineages proposed for the Albitarsis complex and that the mtDNA genome is a more sensitive indicator of that divergence (Zink \& Barrowclough 2008).

As with other species complexes, females of the Albitarsis complex are difficult to distinguish using the available morphological keys. They may exhibit high intraspecific morphological variability (Rubio-Palis et al. 2003) and also interspecific similarity; hence, multivariate analysis of measurements of morphological features (Motoki et al. 2009) and molecular analyses based on mtDNA sequences have been shown to be effective approaches for distinguishing among morphologically similar species in the complex (Lehr et al. 2005).

A recent population genetics study using microsatellite markers detected population structure for $A n$. marajoara in Colombia (Brochero 2006, Brochero et al. 2010). These authors found that populations at different locations in Colombia showed departures from HardyWeinberg equilibrium associated with heterozygote deficits because of the Wahlund effect. However, a different study (Posso et al. 2006), using random amplification of polymorphic DNA-PCR, reported the occurrence of gene flow among An. marajoara populations from eastern and western Colombia that was higher among the eastern populations. Results of the present study, based on the phylogenetic analyses of COI sequences, suggest the presence of more than one species of the Albitarsis complex in Colombia. Therefore, results of the previous studies may have been biased, as only Brochero et al. (2010) included molecular analyses to support or confirm species identification. The differentiation detected in An. marajoara populations from Colombia may have two possible explanations. First, the genetic variation observed among An. marajoara populations from Colombia may be influenced by allopatric distribution (potential isolation by distance) in addition to possible reproductive isolation. Second, different lineages/species of An. albitarsis s.l., particularly a new lineage closely related to $A n$. janconnae, may be present in these areas of Colombia.

In this study, MP, ML and Bayesian analyses of COI sequences of An. albitarsis s.l. from Colombian Caribbean specimens were grouped into a strongly supported clade together with a single sequence reported as An. albitarsis E from Venezuela, as well as grouped separately from the monophyletic lineage of An. janconnae (Fig. 3 and Supplementary data). However, a low to moderate level of genetic variability was detected among the specimens forming the An. janconnae clade and samples from Colombia, as might be expected for mosquitoes from different populations. In summary, the topology of all optimal trees under MP, ML, and Bayesian methods, in addition to the strong nodal support and the values of genetic distance calculated for An. albitarsis s.l. specimens from the Caribbean localities, showed that a new lineage closely related to An. janconnae is distributed 
in this region. The occurrence of a new lineage closely related to An. janconnae in sympatry with other known malaria vectors in the Caribbean region (Gutiérrez et al. $2008,2009)$ adds additional complexity to the understanding of malaria transmission dynamics in Colombia, as An. janconnae is known as a locally important malaria vector in Brazil. Further studies will be essential to verify if this putative species plays an important role as a secondary or local vector in the Caribbean region of Colombia. Also, these data suggest that more intensive morphological and molecular characterization of the species of the Albitarsis complex not only from Colombia but throughout their distribution in the Neotropical biogeographic region should be undertaken to complete the descriptions of the unknown life stages for all members of this complex (for instance, fourth-instar larvae and pupae of An. janconnae and species $\mathrm{F}$ remain undescribed), including the putative new lineage suggested here.

\section{ACKNOWLEDGEMENTS}

To RC Wilkerson, Walter Reed Systematics Unit, Smithsonian Institution, Washington, DC, for a thorough review of an earlier draft of this manuscript.

\section{REFERENCES}

Birungi J, Munstermann LE 2002. Genetic structure of Aedes albopictus (Diptera: Culicidae) populations based on mitochondrial ND5 sequences: evidence for an independent invasion into Brazil and United States. Ann Entomol Soc Am 95: 125-132.

Bourke BP, Foster PG, Bergo ES, Calado DC, Sallum MA 2010. Phylogenetic relationships among species of Anopheles (Nyssorhynchus) (Diptera, Culicidae) based on nuclear and mitochondrial gene sequences. Acta Trop 114: 88-96.

Brelsfoard CL, Fritz GN, Rodriguez R 2006. Identification of Anopheles (Nyssorhynchus) marajoara (Diptera: Culicidae) in Bolivia using polymerase chain reaction and a restriction endonuclease. Ann Entomol Soc Am 99: 707-713.

Brochero HH, Li C, Wilkerson RC 2007. A newly recognized species in the Anopheles (Nyssorhynchus) albitarsis complex (Diptera: Culicidae) from Puerto Carreno, Colombia. Am J Trop Med Hyg 76: 1113-1117.

Brochero HL 2006. Estructura genética poblacional de Anopheles (Nyssorhynchus) marajoara Galvão \& Damasceno 1942 (Diptera: Culicidae) en Colombia, PhD Thesis, Pontificia Universidad Javeriana, Bogotá, 192 pp.

Brochero HL, Li C, Wilkerson R, Conn JE, Ruiz-García M 2010. Genetic structure of Anopheles (Nyssorhynchus) marajoara (Diptera: Culicidae) in Colombia. Am J Trop Med Hyg 83: 585-595.

Brochero HL, Rey G, Buitrago LS, Olano VA 2005. Biting activity and breeding sites of Anopheles species in the municipality Villavicencio, Meta, Colombia. J Am Mosq Control Assoc 21: 182-186.

Conn JE, Wilkerson RC, Segura MN, de Souza RT, Schlichting CD, Wirtz RA, Póvoa MM 2002. Emergence of a new neotropical malaria vector facilitated by human migration and changes in land use. Am J Trop Med Hyg 66: 18-22.

González R, Carrejo N 2007. Introducción al estudio taxonómico de Anopheles de Colombia: claves y notas de distribución, Universidad del Valle, Cali, 237 pp.

Gutiérrez LA, González JJ, Gómez GF, Castro MI, Rosero DA,
Luckhart S, Conn JE, Correa MM 2009. Species composition and natural infectivity of anthropophilic Anopheles (Diptera: Culicidae) in the states of Córdoba and Antioquia, Northwestern Colombia. Mem Inst Oswaldo Cruz 104: 1117-1124.

Gutiérrez LA, Naranjo N, Jaramillo LM, Muskus C, Luckhart S, Conn JE, Correa MM 2008. Natural infectivity of Anopheles species from the Pacific and Atlantic Regions of Colombia. Acta Trop 107: 99-105.

Hijmans RJ, Guarino L, Cruz M, Rojas E 2001. Computer tools for spatial analysis of plant genetic resources data: 1. DIVA-GIS. Plant Genet Resour Newsl 127: 15-19.

INS - Instituto Nacional de Salud 2007. Boletín Epidemiológico Semanal. Estadísticas del Sistema de Vigilancia en Salud Pública - SIVIGILA, Casos totales en la semana epidemiológica 52 y acumulados del año, Subdirección de Vigilancia y Control en Salud Pública, Bogotá, Available from: http://www.ins.gov. $\mathrm{co} /$ ?idcategoria $=6003$.

Klein TA, Lima JB, Tada MS 1991a. Comparative susceptibility of anopheline mosquitoes to Plasmodium falciparum in Rondonia, Brazil. Am J Trop Med Hyg 44: 598-603.

Klein TA, Lima JB, Tada MS, Miller R 1991b. Comparative susceptibility of anopheline mosquitoes in Rondonia, Brazil, to infection by Plasmodium vivax. Am J Trop Med Hyg 45: 463-470.

Lehr MA, Kilpatrick CW, Wilkerson RC, Conn JE 2005. Cryptic species in the Anopheles (Nyssorhynchus) albitarsis (Diptera: Culicidae) complex: incongruence between random amplified polymorphic DNA-polymerase chain reaction identification and analysis of mitochondrial DNA COI gene sequences. Ann Entomol Soc Am 98: 908-917.

Li C, Wilkerson RC 2005. Identification of Anopheles (Nyssorhynchus) albitarsis complex species (Diptera: Culicidae) using rDNA internal transcribed spacer 2-based polymerase chain reaction primes. Mem Inst Oswaldo Cruz 100: 495-500.

Li C, Wilkerson RC 2007. Intragenomic rDNA ITS2 variation in the neotropical Anopheles (Nyssorhynchus) albitarsis complex (Diptera: Culicidae). J Hered 98: 51-59.

Lunt DH, Zhang DX, Szymura JM, Hewitt GM 1996. The insect cytochrome oxidase I gene: evolutionary patterns and conserved primers for phylogenetic studies. Insect Mol Biol 5: 153-165.

Merritt TJ, Young CR, Vogt RG, Wilkerson RC, Quattro JM 2005. Intron retention identifies a malaria vector within the Anopheles (Nyssorhynchus) albitarsis complex (Diptera: Culicidae). Mol Phylogenet Evol 35: 719-724.

Mirabello L, Conn JE 2008. Population analysis using the nuclear white gene detects Pliocene/Pleistocene lineage divergence within Anopheles nuneztovari in South America. Med Vet Entomol 22: 109-119.

Motoki MT, Wilkerson RC, Sallum MA 2009. The Anopheles albitarsis complex with the recognition of Anopheles oryzalimnetes Wilkerson and Motoki, n. sp. and Anopheles janconnae Wilkerson and Sallum, n. sp. (Diptera: Culicidae). Mem Inst Oswaldo Cruz 104: 823-850.

PAHO - Pan American Health Organization 2007. Technical notes \& sources: health situation in the Americas: basic indicators, Regional Core Health Data and Country Profiles Initiative, Washington, DC. Available from: http://www.paho.org/english/ dd/ais/coredata.htm.

Posada D 2006. ModelTest Server: a web-based tool for the statistical selection of models of nucleotide substitution online. Nucleic Acids Res 34: 700-703. 
Posso CE, González R, Cárdenas H, Tascón Y 2006. Estructura genética de Anopheles darlingi Root, An. nuneztovari Gabaldon y An. marajoara Galvão \& Damasceno de Colombia mediante RAPDPCR. Rev Colomb Entomol 32: 49-56

Póvoa MM, de Souza RT, Lacerda RN, Rosa ES, Galiza D, de Souza JR, Wirtz RA, Schlichting CD, Conn JE 2006. The importance of Anopheles albitarsis E and An. darlingi in human malaria transmission in Boa Vista, state of Roraima, Brazil. Mem Inst Oswaldo Cruz 101: 163-168.

Ronquist F, Huelsenbeck JP 2003. MrBayes 3: Bayesian phylogenetic inference under mixed models. Bioinformatics 19: 1572-1574.

Rosa-Freitas MG 1989. Anopheles (Nyssorhynchus) deaneorum: a new species in the albitarsis complex (Diptera: Culicidae). Mem Inst Oswaldo Cruz 84: 535-543.

Rubio-Palis Y, Wilkerson R, Guzmán H 2003. Morphological characters of adult Anopheles (Nyssorhynchus) marajoara in Venezuela. J Am Mosq Control Assoc 19: 107-114.

Rubio-Palis Y, Zimmerman RH 1997. Ecoregional classification of malaria vectors in the neotropics. J Med Entomol 34: 499-510.

Swofford DL 2000. PAUP* version 4.0. Phylogenetic analysis using parsimony (and other methods), Sinauer Associates Inc, Sunderland, Massachusetts.

Tamura K, Dudley J, Nei M, Kumar S 2007. MEGA4: Molecular Evolutionary Genetics Analysis (MEGA) software version 4.0. Mol Biol Evol 24: 1596-1599.

Tavaré S 1986. Some probabilistic and statistical problems in the analysis of DNA sequences. In RM Miura, Some mathematical questions in biology: DNA sequence analysis (lectures on mathematics in the life sciences), Amer Mathematical Society, Providence, p 57-86.

Thompson JD, Gibson TJ, Plewniak F, Jeanmougin F, Higgins DG 1997. The CLUSTALX windows interface: flexible strategies for multiple sequence alignment aided by quality analysis tools. Nucleic Acids Res 25: 4876-4882.

Wilkerson RC, Foster PG, Li C, Sallum MA 2005. Molecular phylogeny of neotropical Anopheles (Nyssorhynchus) albitarsis species complex (Diptera: Culicidae). Ann Entomol Soc Am 98: 918-925.

Wilkerson RC, Gaffigan TV, Bento Lima J 1995a. Identification of species related to Anopheles (Nyssorhynchus) albitarsis by random amplified polymorphic DNA-polymerase chain reaction (Diptera: Culicidae). Mem Inst Oswaldo Cruz 90: 721-732.

Wilkerson RC, Parsons TJ, Klein TA, Gaffigan TV, Bergo E, Consolim J 1995b. Diagnosis by random amplified polymorphic DNA polymerase chain reaction of four cryptic species related to Anopheles (Nyssorhynchus) albitarsis (Diptera: Culicidae) from Paraguay, Argentina, and Brazil. J Med Entomol 32: 697-704.

Zapata MA, Cienfuegos AV, Quirós OI, Quiñones ML, Luckhart S, Correa MM 2007. Discrimination of seven Anopheles species from San Pedro de Uraba, Antioquia, Colombia, by polymerase chain reaction-restriction fragment length polymorphism analysis of its sequences. Am J Trop Med Hyg 77: 67-72.

Zink RM, Barrowclough GF 2008. Mitochondrial DNA under siege in avian phylogeography. Mol Ecol 17: 2107-2121. 


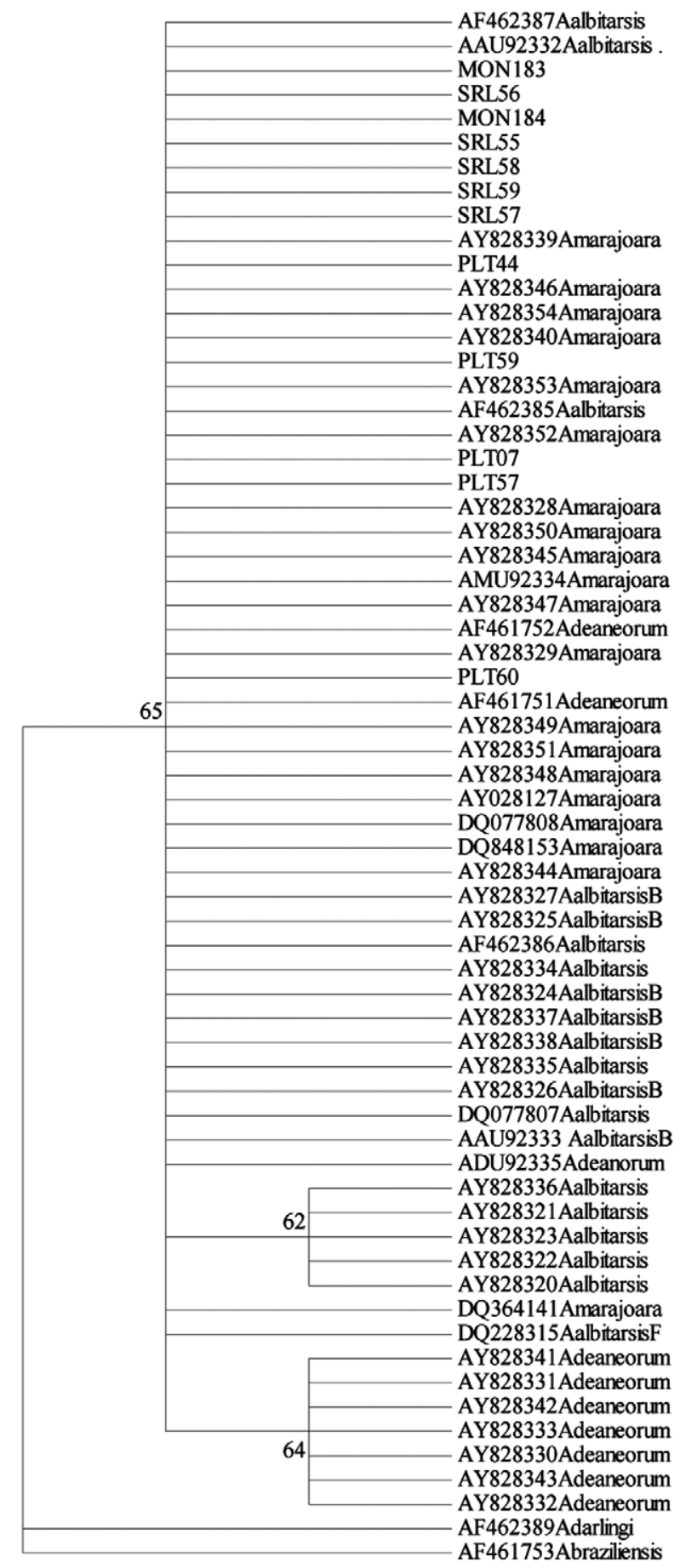

Neighbour-joining analyses based on 64 internal transcribed spacer 2 sequences from individuals of the different species of Albitarsis complex. The percentage of replicate trees in which the associated taxa clustered together in the bootstrap test (1,000 replicates) is shown next to the branches, retaining only groups with frequency $\geq 60 \%$. Outgroups are Anopheles darlingi and Anopheles braziliensis. 


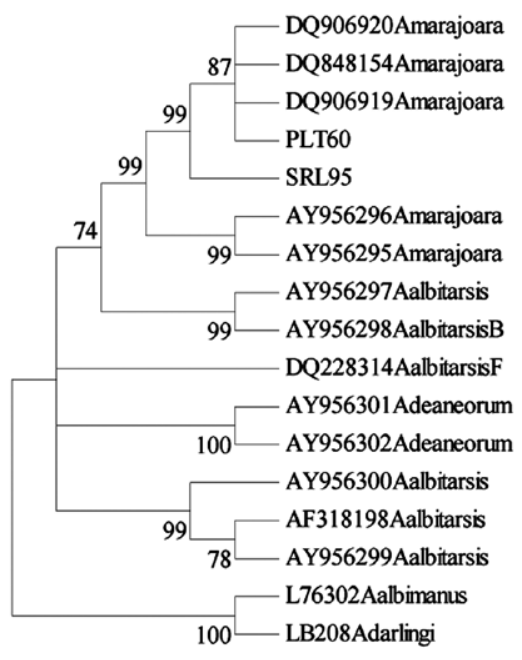

Neighbour-joining analyses based on 17 partial nuclear DNA white gene sequences. The percentage of replicate trees in which the associated taxa clustered together in the bootstrap test (1,000 replicates) is shown next to the branches, retaining only groups with frequency $\geq$ 60\%. Outgroups are Anopheles darlingi and Anopheles albimanus.

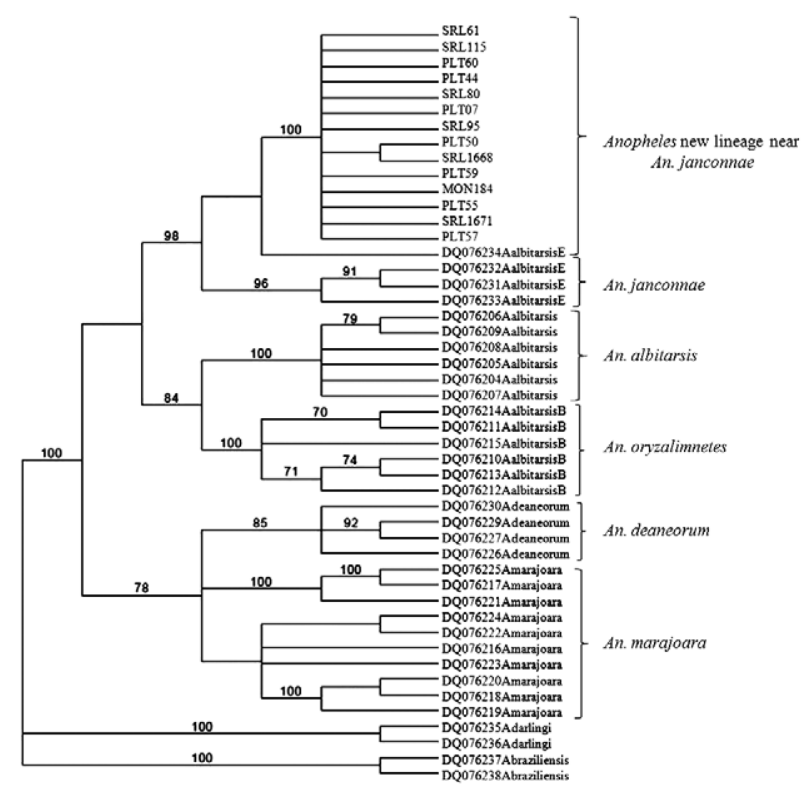

Maximum parsimony tree based on cytochrome oxidase I gene sequences. Numbers above branches indicate the percentage of replicate trees in which the associated taxa clustered together in the bootstrap test (1,000 replicates). DQ076234: An. albitarsis E (?) specimen from Portuguesa, Venezuela; Anopheles albitarsis E (?) specimen from Portuguesa, Venezuela; DQ076231-DQ076233: An. albitarsis E (Anopheles janconnae) from the type locality in Roraima, Brazil. Bootstrap values $>70 \%$ are shown. Outgroup comprises Anopheles darlingi and Anopheles braziliensis. 


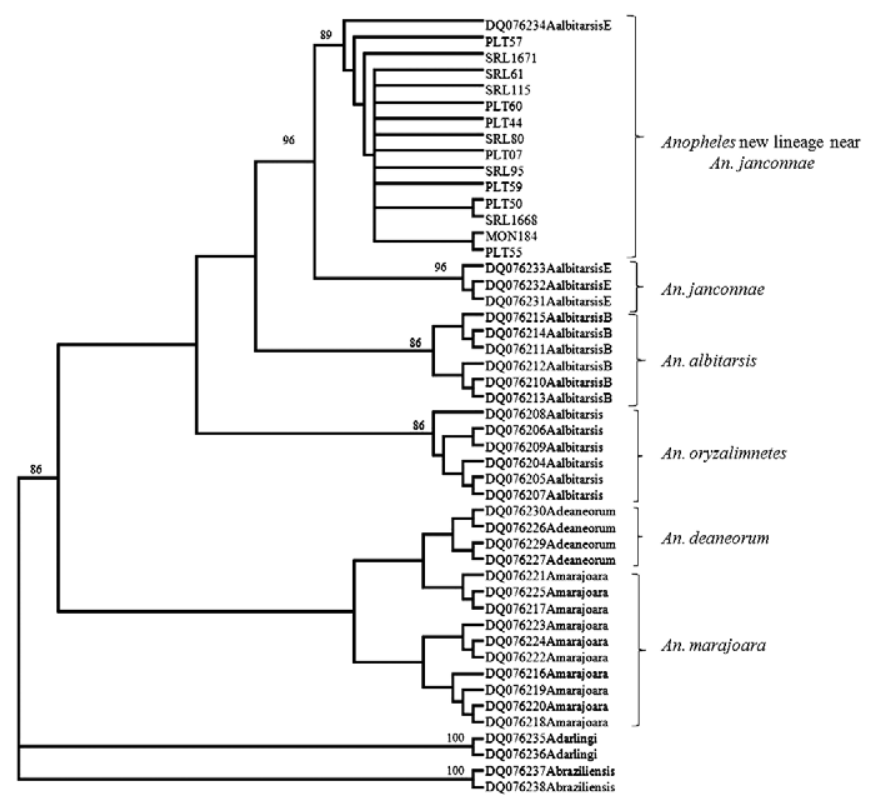

Maximum likelihood (ML) tree based on cytochrome oxidase I gene sequences. Numbers above branches indicate ML bootstrap proportions (662 replicates). DQ076234: Anopheles albitarsis E (?) specimen from Portuguesa, Venezuela; DQ076231-DQ076233: An. albitarsis E (Anopheles janconnae) from the type locality in Roraima, Brazil. Bootstrap values $>70 \%$ are shown. Outgroup comprises Anopheles darlingi and Anopheles braziliensis. 